\title{
Motion, Commotion, and Biophysical Connections at Deep Ocean Seamounts
}

BY J. WILLIAM LAVELLE

AND CHRISTIAN MOHN

Figure 1. The cone and caldera of Brothers Volcano along the Kermadec arc northeast of New Zealand (de Ronde et al., 2005). The caldera rim, located at 1400-m depth, has lateral dimensions of $\sim 3 \times 4 \mathrm{~km}$. The surrounding ocean depth is approximately $2200 \mathrm{~m}$. The bathymetric data are courtesy of New Zealand Institute of Water \& Atmospheric Research (NIWA), and their three-dimensional representation is courtesy of the NOAA Vents program. Vertical exaggeration is $3 \mathrm{x}$. (For animated caldera fly-throughs at Kermadec arc and Mariana arc, respectively, see http://oceanexplorer.noaa.gov/explorations/05fire/background/kermadecarc/kermadecarc.html and http://oceanexplorer.noaa.gov/explorations/06fire/background/marianaarc/marianaarc.html.) 
ABSTRACT. Seamounts attract the attention of physical oceanographers for a variety of reasons: seamounts play a special role in ocean biology; they may be hydrothermally and magmatically active and thereby feed the ocean with heat, chemical constituents, and microbes; they help convert ocean tidal energy into smaller-length waves and turbulence that affect the ocean locally and globally; and they act, in effect, as sources and sinks of ocean eddies. From a physical oceanographic perspective, the interaction of passing ocean flows with seamount topography is rich in outcomes. That richness originates in the global variability of seamount height and shape, seamount latitude, local ocean stratification, the amplitude and time dependence of the passing flow, as well as many secondary factors, such as proximity to neighboring topography. All these together determine the nature of the circulation, local hydrographic distributions, turbulence, and transport around a seamount. Here we summarize important concepts of ocean physics at seamounts and recount some of the settings in which this physics plays out. Selected aspects of biophysical coupling are also highlighted, particularly the loss and retention of particles, which are connected to a seamount's ability to sustain biological and biologically important property distributions in the face of impinging flows.

\section{INTRODUCTION}

The world ocean is ubiquitously dotted with seamounts (Wessel et al., 2010), isolated or clustered, usually volcanogenic, features rising off the seafloor many hundreds of meters or more (e.g., Figure 1). As obstacles to ocean flow, seamounts alter ocean conditions locally and, as more recently understood, globally. There are at least four reasons that oceanographers are attracted to seamounts. First, seamounts can be sites of enhanced productivity, biomass, and diversity-ocean biological oases, whose contributions to marine ecology are increasingly appreciated. Seamounts can serve as habitats and hot spots of marine life, especially in open ocean areas of otherwise low productivity and biodiversity (e.g., Rogers, 1994). The dark side of that resource recognition has been unsustainable exploitation and collapse of seamount fisheries in most regions (e.g., Koslow, 1997; Clark, 2001; Pitcher et al., 2010). Second, some seamounts are hydrothermally and possibly magmatically active. The hot water and chemicals that issue from Earth's crust at these sites sustain colonies of previously unknown fauna and microbes, whose ultimate ecological effects and benefits to humans are still largely unknown. The discharges also provide clues about crustal composition and processes. Third, seamounts act as ocean stirring rods, sites where some of the energy from lunar and solar tides are converted to internal tides, oscillatory motions of ocean internal density surfaces (e.g., Garrett, 2003). This extraction of energy from surface tides by seamounts (and mid-ocean ridges) begins a cascade of energy toward the smaller length scales of turbulence. The distribution of ocean turbulent mixing intensity, both vertical and lateral, influences large-scale ocean and local circulation patterns.

Fourth, seamounts are known to be sites of ocean eddy creation (e.g., Royer, 1978) and destruction (e.g., Herbette et al., 2003). Motion (circulation) and commotion (turbulence) at seamounts thus can have far-reaching and local consequences, including influencing ocean biological and geochemical distributions.

\section{THE PRIMARY FACTORS}

Far too much work on ocean physics at seamounts exists to write comprehensively about it in a short article, but that work has identified five principal factors (Figure 2) that determine the effects of isolated seamounts on the surrounding ocean (see also White et al., 2007). Those factors are: (1) the height of the seamount $\left(h_{m}\right)$ relative to the height of the local ocean $(H)$; (2) the vertical component of Earth's rotation rate $(f / 2)$ determined by its latitude, the consequence of using a rotating (Earth-fixed) coordinate system to express observational results; (3) local density stratification, which depends on the profiles of temperature $(T)$, salinity $(S)$, and ocean pressure $(p)$; $(4)$ the morphology of the seamount, including size (e.g., length scale $L$ ), shape (e.g., conical versus guyot, i.e., a flat-topped seamount), flank slope $(\alpha)$, and to a lesser extent small-scale, unresolved topography; and (5) the energy-frequency distribution of the impinging steady and oscillating currents $\left(U_{\text {mean }}\right.$ and $\left.U_{v a r}\right)$ and eddies. In the case of hydrothermally or magmatically active seamounts, the heat $\left(Q_{T}\right)$ and/or salt $\left(Q_{S}\right)$ flux out of Earth's crust may cause additional changes in local circulation and hydrography. Secondary factors sometimes have to be considered as well: for shallow seamounts, for example, surface wave conditions, and for paired or chained seamounts or seamounts situated near other topography, the flow resulting from proximal topographic interactions. Local flow is also influenced by local turbulence, but 


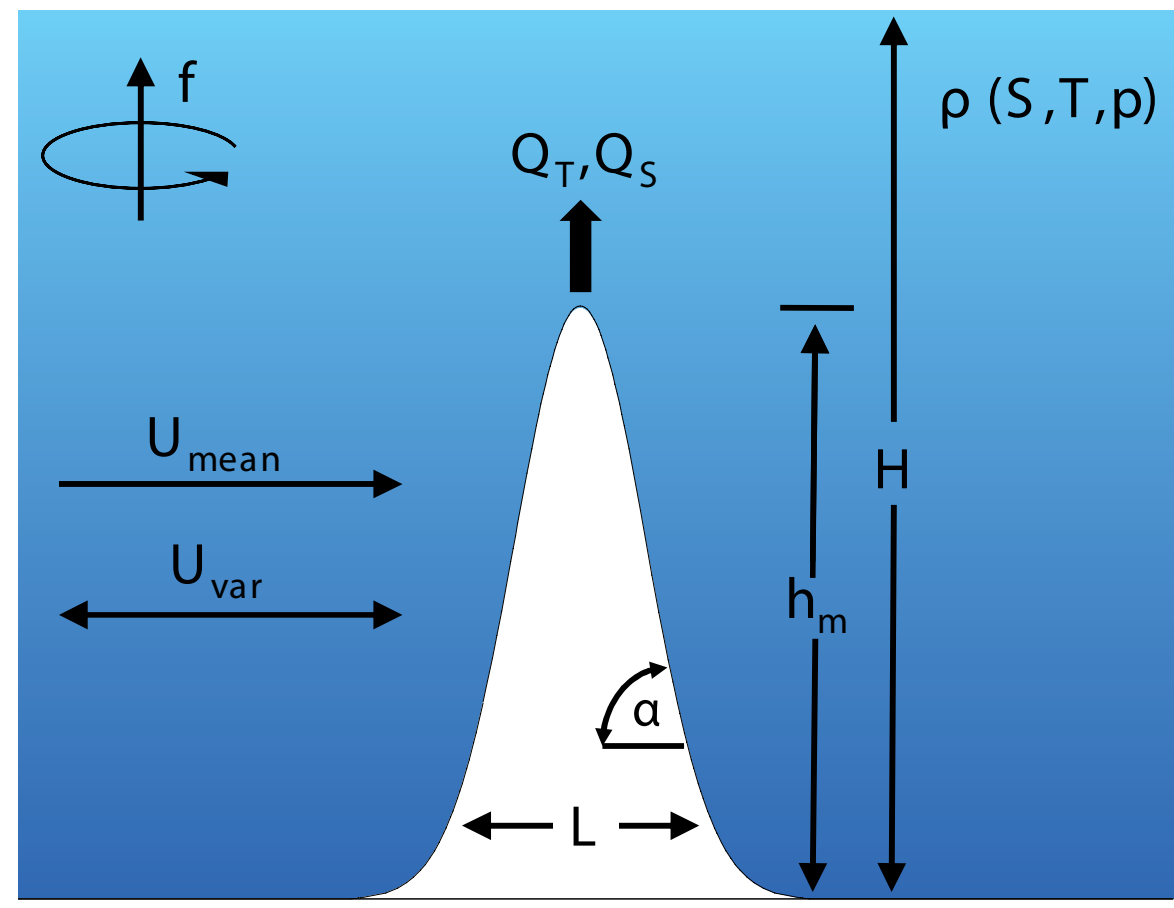

Figure 2. Primary factors determining the character of flow at a seamount. Fractional seamount height $\left(h_{M} / H\right)$; the vertical component of Earth's rotation rate $(f / 2)$; local ocean density stratification $(\rho)$, which depends on salinity $(S)$, temperature $(T)$, and pressure $(p)$; seamount morphology (e.g., $L$ and slope $a$ ); impinging steady and oscillating currents $\left(U_{\text {mean }}, U_{v a r}\right)$; and, in the case of hydrothermally active seamounts, fluxes of heat and salt $\left(Q_{T}, Q_{S}\right)$.

much of this "commotion" is likely to have been generated on the spot by way of current shears caused by the interaction of impinging flows, ocean stratification, and seamount topography. With so many controlling and secondary factors, it is not difficult to see why the consequences of the physics at each and every seamount might be different.

\section{BASIC CIRCULATION FEATURES Steady Impinging Flows}

Some of the earliest work relevant to flow over topography took place in the laboratory nearly 100 years ago (Sidebar 1). More directly relevant to ocean seamounts was consideration of steady flow over obstacles in rotating, stratified environments (Hogg, 1973; Schär and Davies, 1988). This led to the concept of a Taylor cap, an isolated region of flow situated above the topography, but a region that had only limited height. Transient unidirectional flows were used to investigate how a Taylor cap might form. Those studies (e.g., Huppert and Bryan, 1976; Verron and Le Provost, 1985; Chapman and Haidvogel, 1992) showed that flow transitioning to equilibrium would first cause two counter rotating vortices to form over their idealized Gaussianshaped seamounts, but the cyclonic vortex would ultimately be shed downstream, leaving just the anti-cyclonic circulating Taylor cap behind. If velocities are too large, however, a persistent Taylor cap will not form. A domelike density anomaly entrapping cold water over the summit is an accompanying feature. The Taylor cap has had some notoriety among seamount researchers because a stationary recirculating feature might be just the ticket for retention of, for example, plankton at the seamount summit. Needless to say, the likelihood of occurrence and the properties of a Taylor cap will depend on the conditions of all five principal factors identified earlier (e.g., Chapman and Haidvogel, 1992). Furthermore, a Taylor cap is a concept wedded exclusively to unidirectional steady flow. Although a few have been reported in the field (Owens and Hogg, 1980), the likelihood of Taylor cap formation at seamounts and their possible role in particle retention should not be overemphasized because of the unlikely dominance of the steady flow component at most ocean sites.

\section{Oscillatory Impinging Flows}

Because seamounts are typically bathed by tidal, inertial, and other oscillatory flows (Figure 3), the effects of tides and other waves on seamount circulation were next to draw attention (Chapman, 1989; Brink, 1989, 1990). Resulting effects are divided into two categories separated by the inertial frequency $f$ (or inertial period $\left.T_{f}=2 \pi / f\right)$, the frequency

\section{J.William Lavelle(j.william.lavelle@ noaa.gov) is Physical Oceanographer, Pacific Marine Environmental Laboratory, National Oceanic and Atmospheric}

Administration, Seattle, WA, USA.

Christian Mohn was Postdoctoral Fellow, Department of Earth and Ocean Sciences, National University of Ireland, Galway, Ireland, and is currently Senior Researcher, Department of Marine Ecology, National Environmental Research Institute, Aarhus University, Roskilde, Denmark. 
(or period) of an impulsively displaced particle to return to its initial position on a frictionless rotating plane (Sidebar 2). On the rotating Earth's surface, the relevant angular frequency $f\left(\operatorname{rad~s}^{-1}\right)$ varies by latitude: $f=4 \pi \sin (\varphi) / T_{24}$, where $T_{24}$ is a solar day and $\varphi$ is latitude. Incoming oscillations to a seamount with frequencies less than $f$ affect the local flow around the seamount in one way, while those with higher frequencies affect it in another way. For any given incident-wave frequency, the latitude of the seamount determines on which side of that divide the local response will fall (Sidebar 2).

Impinging oscillations with frequencies less than the inertial frequency $f$, the subinertial oscillations (Sidebar 2), are amplified in the vicinity of the seamount (e.g., Eriksen, 1991; Codiga and Eriksen, 1997). Over Fieberling Guyot, diurnal tidal currents are amplified more than a factor of 10 (Brink, 1995). Because the amplification falls off in magnitude with distance from the seamount, the oscillations are said to be trapped to the topography. Of course, the amount of amplification will depend on many factors,

Figure 3. Characteristic features of motion at an isolated seamount (Northern Hemisphere). Anticyclonic-horizontal circulation, isopycnal doming, and a vertical circulation cell, all near summit depth, superimposed on oscillatory currents and oscillatory temperature and salinity distributions. The occurrence, properties, and variability of these longer-term features depend on local turbulence $\kappa$, on internal waves $U_{\omega_{i}}$, which propagate both horizontally and vertically, and on large-scale motion (incident mean current $U_{\text {mean }}$, eddies $\tilde{U}_{\text {mean }}$, tidal and other oscillations $U_{\text {var }}$, and, possibly, wind-driven currents $\left.U_{\text {wind }}\right)$. All the site factors represented in Figure 2 also shape these current and hydrographic distributions.

\section{Sidebar 1. Taylor Column}

G.I. Taylor's (1923) celebrated laboratory experiments of flow over "topography" confirmed the surprising prediction of the Taylor-Proudman theorem (Proudman, 1916; Taylor, 1917). The theorem requires that, in a rotating environment, the slow, steady, frictionless flow of a homogeneous fluid past an isolated bottom obstacle of fractional water depth will result in stagnant fluid in the entire column of fluid directly above the obstacle. Taylor approximated those conditions in the laboratory by drawing a short, solid cylinder across the bottom of a rotating tank of water. Sure enough, accounting for laboratory limitations in meeting the theorem's conditions, the water directly above Taylor's solid cylinder sat stagnant while water in the tank flowed around it. That isolated region of fluid above (i.e., the virtual cylinder) is now commonly referred to as a Taylor column. We cite Taylor's work because of its foundational role in studies of flow over topography, but studies by others of the effects of water column stratification were needed to make the results relevant to ocean conditions. Strictly speaking, Taylor columns cannot occur in the real ocean because of stratification. In 1964, the same G.I. Taylor, with an interest in the disintegration of water drops in thunderstorms, examined the conical shape at the end of a drop of liquid in an electric field emitting a jet of fluid. The term Taylor cone consequently came to be used in later work on sprays of various charged droplets in electric fields, and that is the context where that phrase is conventionally used (e.g., Fernandez de la Mora, 2007).

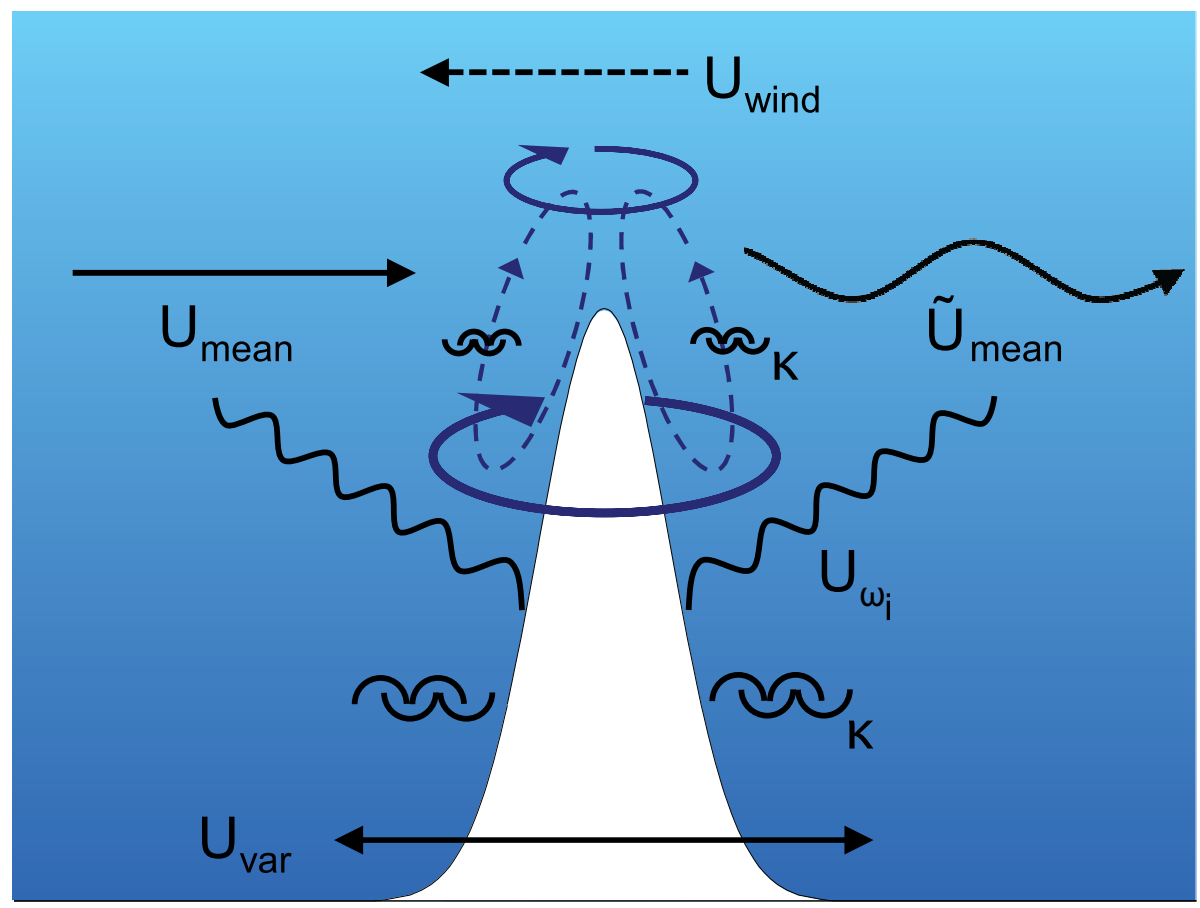




\section{Sidebar 2. Fluid Oscillations in the Ocean}

Periods of fluid oscillations in the ocean range from very long to very short (represented in the line spectrum in red). Ocean oscillations of special significance along that spectrum include diurnal tidal motions (represented by $\mathrm{K}_{1}$, period $=23.93 \mathrm{hrs}$ ) and semi-diurnal tidal motions (represented by $M_{2}$, period $=12.42 \mathrm{hrs}$ ). Two other oscillation periods are highlighted, one that depends on site location and another that depends on the local physical properties of the ocean. The first is the inertial period $T_{f}(=2 \pi / f)$ where $f=12 \mathrm{hr} / \mathrm{sin}$ (latitude), and the second is the buoyancy period $T_{N}(=2 \pi / N)$, where $N$, the buoyancy frequency, varies with the local ocean stratification (see text). The inertial period $\left(T_{f}\right)$ depends on latitude, illustrated here by the solid blue arrow that connects a latitudinal position along the lower line scale (in blue) with an oscillation period on the upper line spectrum (in red). As the latitude decreases, the inertial period grows longer. The buoyancy period, represented by a thick black arrow, varies over a small range at the short period end of the upper line spectrum (in red), its value depending on the vertical gradient in local ocean density.

The position of $T_{f}$ along the line spectrum (red) divides the spectral range of periods larger than the buoyancy period into two parts. At periods shorter than $T_{f}$ but greater than the buoyancy period, oscillations of internal density surfaces in the ocean (internal waves) are generated by the interaction of impinging currents, ocean stratification, and seamount topography. These internal ocean oscillations propagate energy away from the seamount into the distant ocean. In contrast, at periods longer than $T_{f}$, oscillations have larger amplitudes in the near vicinity of the seamount than those of the impinging currents, and those amplitudes decay with distance from the seamount. Oscillations at periods greater than $T_{f}$ are consequently said to be trapped to the seamount. Periods greater than $T_{f}$ are described as subinertial because the corresponding frequencies are lower than the inertial frequency. Note that including the effects of Earth's rotation on the ocean physics of seamounts located at or near the equator requires going beyond the use of a single valued $f$. There, the rapid variation with latitude of the vertical component of Earth's rotation rate requires using alternative approaches.

\section{Ocean Oscillation Spectrum}

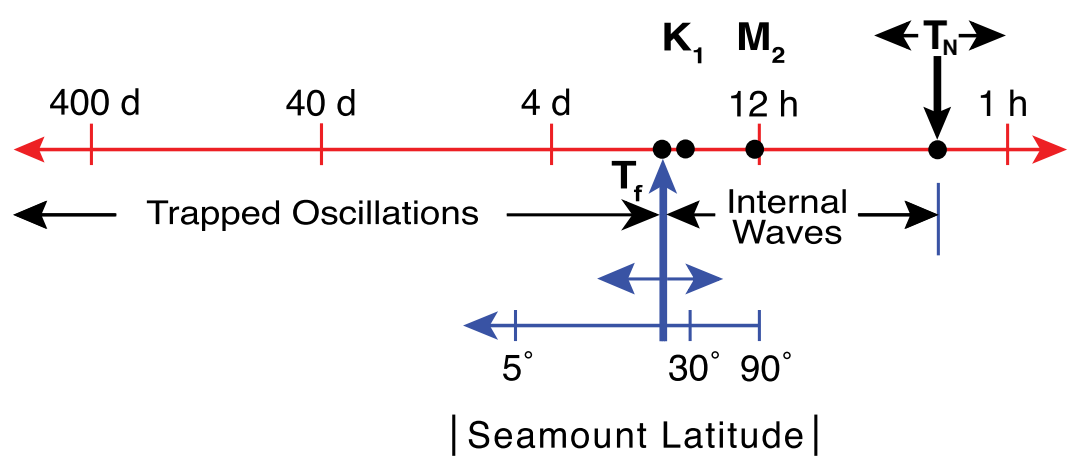

including seamount diameter, fractional water-column height, and slope of the seamount's flanks (Beckmann, 1995). Very wide and steep seamounts show more limited ability to amplify, and topographic deviations from "optimal" symmetric shape also reduce the size of trapped flows (Beckmann, 1995).

At incident-wave frequencies (tidal or otherwise) that are greater than the latitude-dependent frequency $f$ but less than the buoyancy frequency $N$ (see Sidebar 2), waves on density surfaces of the interior ocean (internal waves) are generated and propagate horizontally and vertically away from the seamount (e.g., Eriksen, 1998; Baines, 2007). At tidal frequencies, these internal waves (internal tides) mark the conversion of surface tidal energy into tidalfrequency wave energy of the ocean's internal density surfaces (Garrett and Kunze, 2007). Internal waves are taken up again in a later section.

One further notable aspect of the circulation at some seamounts caused by impinging oscillatory flow can be a steady residual current, or rectified current, that is toroidal. Rectification here refers to the generation of unidirectional flow from oscillatory flow. The toroid is a doughnut of stronger flow that circles anticyclonically around a seamount summit as in Figure 3 (e.g., Brink, 1990; Beckmann and Haidvogel, 1997; Lavelle et al., 2003; Mohn et al., 2009). The shape and size of the toroid, and the speed within it, will depend on seamount morphology, ocean stratification, and spectral content of the incident flow. The radial and vertical circulation patterns associated with rectification (Figure 3) may enhance the retention of particles/biota near 
the seamount summit (Mullineaux and Mills, 1997). However, the oscillatory currents that ultimately cause the rectified flow will also move particles in and out of the toroid and vertical recirculation cell. Rectified anticyclonic flow is not a mandatory feature at seamount summits in the presence of oscillatory currents because not all seamounts have the morphology to support it.

Settings encompassing combined long-period, inertial, tidal, and higherfrequency flows are, of course, most likely in the real ocean. That being the case, the trajectory of a passive particle at any particular seamount is ultimately determined by a superposition of flows of all spectral frequencies. At shallow seamounts, currents may be, in part, a consequence of wind forcing. Where long-period flow has a magnitude comparable to a tidal flow, flow vortices may be repeatedly shed from and advected downstream away from a seamount. Eddy creation and detachment (e.g., Verron and Le Provost, 1985) may be intermittent as well.

\section{VERTICAL CIRCULATION} AND THE COLD DOME

Vertical circulation at seamounts accompanies the horizontal motions just described. Brink (1995) was able to infer downward and then radially outward circulation over the summit of Fieberling Guyot from long-time-series current meter observations. Modeling suggests that such a circulation cell may extend no more than a few hundred meters above a summit. The verticalradial circulation cell is connected (e.g., Lavelle, 2006) to a hydrographic feature called the cold dome, the often observed upward bowing above the seamount summit of time-averaged isotherms with respect to isotherms in the surrounding ocean (e.g., Owens and Hogg, 1980; Roden, 1987; Comeau et al., 1995). Below cold dome depths, isopycnals (i.e., contours of equal density) may plunge where they meet seamount flanks (e.g., Lavelle, 2006; de Steur et al., 2007). Details of the dome, for example, its lateral extent and height, depend on $f$, the stratification, and seamount size (Owens and Hogg, 1980). The radial-vertical circulation cell, with downward flow above the summit, may be particularly relevant to a general downward transport of dissolved nutrients and detritus that might bear on the sustainability of seamount biota, factors identified in, for example, Pitcher and Bulman (2007).

\section{INTERNAL WAVES}

AND TURBULENCE

Oscillatory currents (e.g., tidal) with

frequencies greater than $f$ but less than the local buoyancy frequency $N$ (Sidebar 2) will generate internal waves when encountering seamounts (e.g., Noble and Mullineaux, 1989). $N$ is the frequency of oscillation, after release, of a hypothetical parcel of water in a stratified fluid displaced vertically from its density equilibrium level. For open ocean stratification, the buoyancy period is typically on the order of tens of minutes to several hours. Internal waves (Figure 4A) propagate horizontally and vertically (Figure 4B) away from seamounts in beam patterns that depend on seamount topography (e.g., side slopes) and water-column stratification (e.g., Eriksen, 1998). The interaction converts some of the oscillation (e.g., tidal) energy into wave energy traveling within the ocean's interior, where additional wave-wave interactions can convert it to higher and higher frequencies and ultimately into ocean turbulence (Garrett, 2003; Garrett and Kunze, 2007). In this sense, seamounts alter the distribution of ocean mixing globally, though it is also understood that ocean ridges more than seamounts are responsible for the bulk of that conversion (Holloway and Merrifield, 1999).

Internal waves generated by waveseamount interaction are strongest above the seamount summit. The consequent and much increased spatial variability of currents and resulting enhanced current shears promote the generation of turbulence, the chaotic motion of fluids at small spatial scales. Little more than a decade ago, measurements of turbulence dissipation (e.g., Figure 5A), the loss of energy to random small-scale motion, above this type of topography became available (Lueck and Mudge, 1997; Toole et al., 1997; Kunze and Sanford, 1996; Kunze and Toole, 1997). These observations allowed the inference of diapycnal diffusivity, a measure of the intensity of mixing across ocean density surfaces caused by turbulent motion, to be made (Figure 5B). Profiles of diapycnal diffusivity show intensification near seamounts by more than a factor of 100 with respect to values near $10^{-5} \mathrm{~m}^{2} \mathrm{~s}^{-1}$ in the surrounding ocean (Kunze and Sanford, 1996). If the seamount is tall, the seamount-originated turbulence can help mix the water column all the way to the sea surface. Small-spatialscale turbulence variations should also encourage particle (e.g., plankton) patchiness above seamounts (Beckmann and Mohn, 2002). 


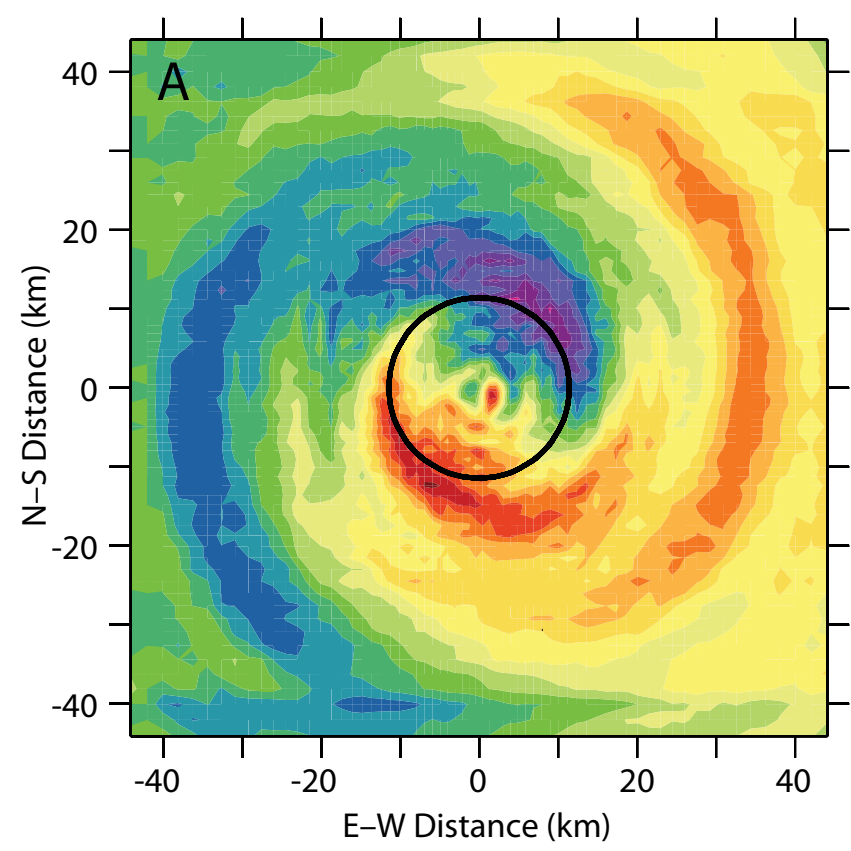
ON PASSING FLOW AND EDDIES

Seamounts and seamount chains also affect the coherent (meaning nonwavelike) ocean flows that they intercept. Roden (1987) describes the Kuroshio current off Japan after encountering the Emperor seamount chain, where seamounts are arranged like irregularly spaced teeth on a $2400-\mathrm{km}$-long comb, some rising to within several hundreds of meters of the sea surface. These obstructions cause stream deflections, large eddy generation, stream energy loss, and local flow intensifications. The consensus, but not unanimous, view is

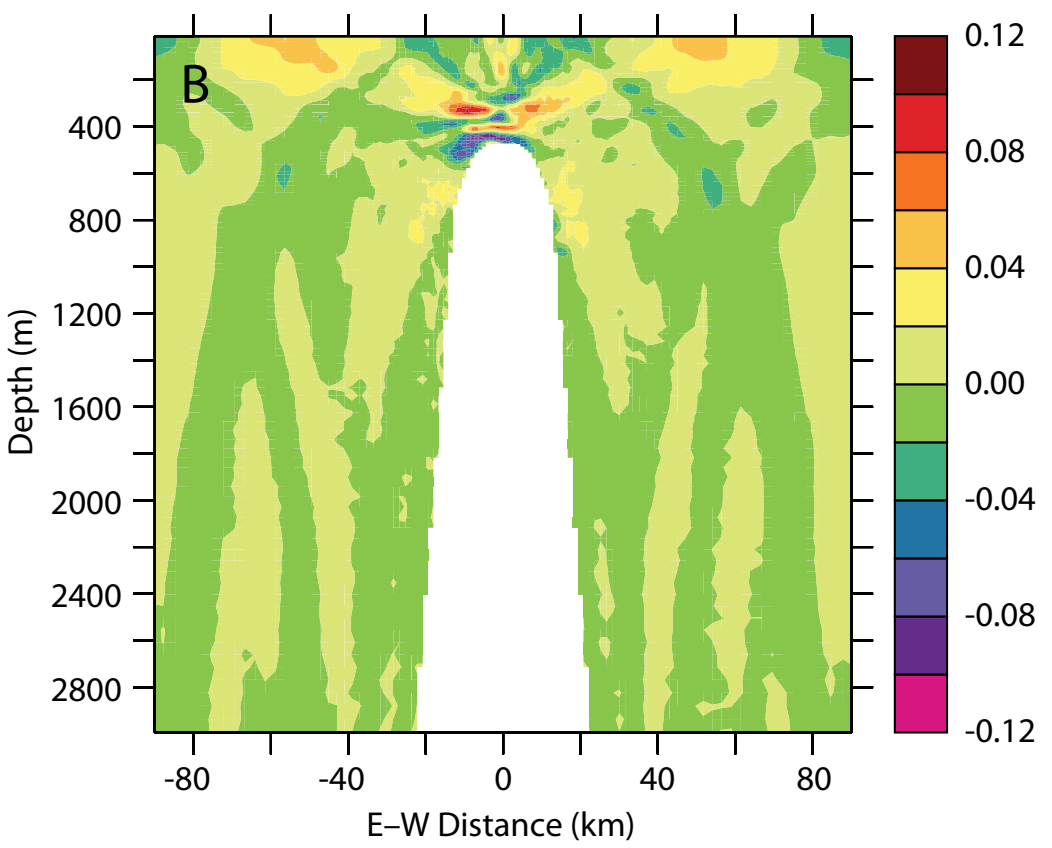

Figure 4. (A) A snapshot of temperature anomaly on a horizontal plane at depth of $200 \mathrm{~m}$, some $280 \mathrm{~m}$ above the summit of the idealized Northern Hemisphere seamount (as in B) subject to impinging multifrequency oscillatory currents from an archived deep-sea current meter record. The anomalies represent the up-down displacement of ocean isotherms, which are the internal waves resulting from the interaction of impinging flow, stratification, and seamount topography. These temperature anomaly waves move radially outward while rotating clockwise (in this example) with time in pinwheel fashion. The circle is the 1000-m depth contour. (B) A vertical section at a different instant and different horizontal scale of just that part of the $\mathrm{E}-\mathrm{W}$ (zonal) velocity associated with oscillations of internal density surfaces. Internal waves can result in greatly increased fluid shears and turbulence over a summit. that the New England seamount chain has a dissipative effect on the Gulf Stream, even though the seamounts lie at a considerable depth below it (e.g., Ezer, 1994). Stream-seamount interactions have also been studied in the laboratory (e.g., Zhang et al., 1994).

Isolated ocean eddies run afoul of seamounts, too. Richardson et al. (2000) estimated that some $90 \%$ of meddies, large rotating subsurface salty boluses of Mediterranean water that are spawned in the Straits of Gibralter and that travel westward in the Atlantic, are altered to various degrees or even destroyed by collisions or near-collisions with seamounts. Bashmachnikov et al. (2009) reported individual meddies colliding with Sedlo and Seine seamounts, with each meddy having a distinctly different interaction with its target seamount before escaping. Meddies have been reported to have spawned daughter eddies after passing between adjacent seamounts (Shapiro et al., 1995). Large surface-expressed eddies spawned by the Agulhas currents in the southern Atlantic are thought to undergo similar 
interactions, with results ranging from slight changes, to eddy trapping, to eddy splitting, to eddy destruction (e.g., Sutyrin, 2006). Bograd et al. (1997) observed the trapping of passing ocean eddies by the Emperor seamounts in the North Pacific and estimated that trapping duration can be as long as several months. Many other laboratory, theoretical, and numerical studies address this type of seamount-flow interaction (e.g., Cenedese, 2002; Nycander and Lacasce, 2004).

\section{HYDROTHERMALLY ACTIVE} SEAMOUNTS AND VOLCANOES

Not to be overlooked is the fact that some seamounts are hydrothermally or magmatically active, or both. Indeed, the list of identified, active undersea volcanoes is growing (e.g., Embley et al., 2007), with the worldwide inventory presently estimated to exceed 160 (Baker et al., 2008). For those seamounts that are hydrothermally active, hot chemicalladen hydrothermal fluid discharges (e.g., Resing et al., 2007) provide a source of local buoyancy that leads to vertical convection. Entrainment of fluid and particles at the base of upward convecting hydrothermal fluid columns locally redistribute seafloor fluids, particles, and biota, often by as much as several hundreds of meters above the seamount summit. Active hydrothermal venting is more often than not first detected by anomalies in hydrographic and particulate distributions in the few hundred meters above the seafloor (e.g., Baker et al., 2008). The discharge of heat, chemicals, and microbes by such vents is a consequence of ocean water circulating into Earth's crust, there to be heated by relatively shallow lenses

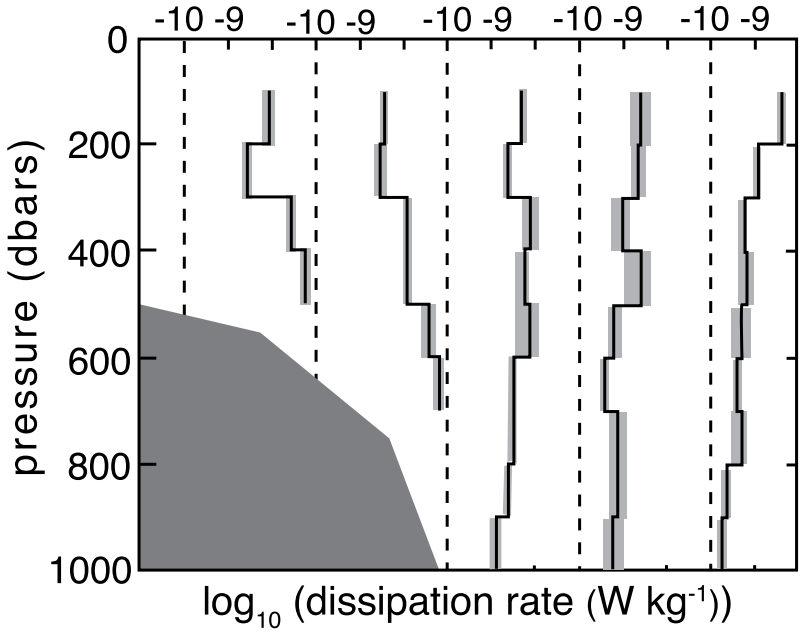

B

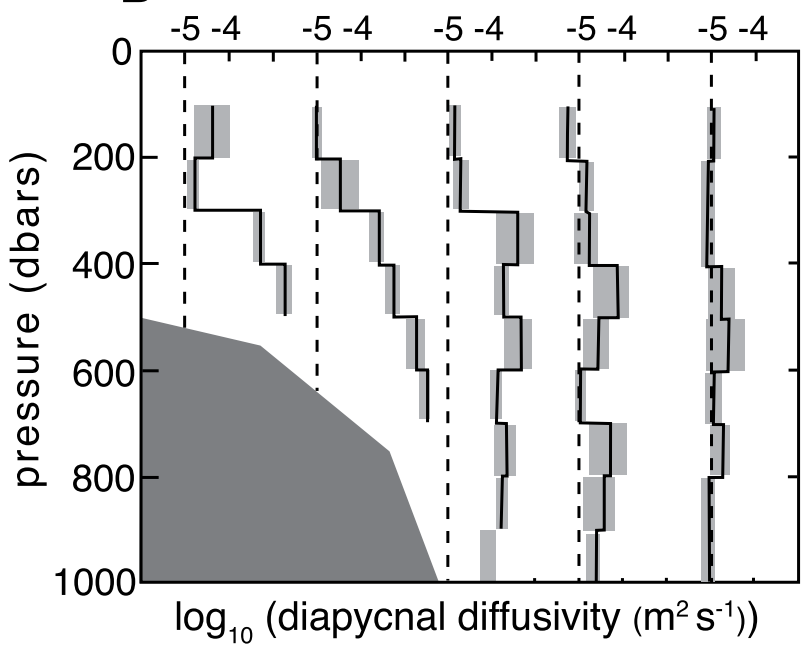

Figure 5. Profiles of (A) turbulence dissipation rate, the rate of energy loss to random, small-scale motion, and (B) diapycnal diffusivity, a measure of the intensity of mixing across (dia-) ocean density (pycno-) surfaces caused by turbulent motion, with depth and distance from the center of Fieberling Guyot (Kunze and Toole, 1997). Diapycnal diffusivity is intensified by a factor $>100$ with respect to background values near the seamount summit. Values in the open ocean away from boundaries are characteristically $10^{-5} \mathrm{~m}^{2} \mathrm{~s}^{-2}$. Diagram (redrawn) courtesy of the American Meteorological Society of hot magma. Other phenomena that occur less frequently at seamounts than at ridge crests are discharges that lead to megaplumes, anomalously warm anticyclonically rotating boluses of water often $>10 \mathrm{~km}$ in diameter and several hundred meters thick located as much as $\sim 1000 \mathrm{~m}$ above their depth of origin. Megaplumes may result from the sudden cracking of Earth's surficial crust that accompanies an intrusion of magma, allowing the release of a large volume of impounded, hot water. In responding to seismic evidence that such a cracking event had occurred, Baker et al. (1999) gathered evidence suggesting that a megaplume had been birthed at Axial
Volcano, a seamount that straddles the Juan de Fuca Ridge in the Northeast Pacific. Estimating the total heat flux with a high degree of confidence for seamounts discharging hydrothermal fluids remains an open problem.

Somewhat common to this class of seamounts is the occurrence of one or more summit calderas (e.g., Figure 1). Hydrothermal sources are typically located on the walls or floors of such calderas (e.g., Staudigel et al., 2006). Calderas also provide additional circulation possibilities. Rectified flows within a large, well-formed caldera will circulate in the opposite sense to the rectified flow on the caldera's exterior. The caldera 
may also serve to retard the outward dispersion of fluids whose chemical and hydrologic signatures are being altered by hydrothermal discharge within the caldera itself. Oscillatory flow across the top of the caldera will induce vertical motion that can periodically flush fluid over the caldera rim, and longer-period flow across the top of the caldera that can draw off those fluids as well. Lessperfectly formed calderas, for example, with breaches in their crater walls, open up a large range of possibilities for circulation and transport.

Observations of actively erupting and discharging undersea volcanoes (see http://oceanexplorer.noaa.gov/ explorations/05fire/logs/photolog/ photolog.html) are providing some surprises. At least one has been observed to be discharging elemental sulfur in liquid form (Embley et al., 2007) and another discharging liquid $\mathrm{CO}_{2}$ (Lupton et al., 2006), which then mixes with surrounding waters on ascent. These affect buoyancy locally. Particulateladen discharges from undersea volca- their relationships to fluid circulation, both above and below the seafloor, are subjects of considerable research activity.

\section{BIOPHYSICAL COUPLING}

The circulation, hydrography, turbulent mixing, and possibly the heat and chemicals released at active venting sites and their spatial and temporal variability all bear on populations of seamount biota and their sustainability. Biophysical coupling at seamounts takes a variety of forms (Genin and Boehlert, 1985; Genin, 2004; Genin and Dower, 2007).

Here, the emphasis is on circulation and turbulence as mechanisms shaping distributions of, specifically, lowertrophic-level biota. The swimming capabilities of some plankton (nekton) might be used to help maintain population distributions around these topographies (e.g., Wilson and Boehlert, 2004; Genin, 2004), but that mechanism is not considered here. We focus on two important aspects of biophysical coupling at seamounts: (1) the shaping of distributions around a seamount summit, and

$\checkmark$ AS IS TRUE IN OTHER AREAS OF OCEAN SCIENCE, AT SEAMOUNTS THERE IS PLENTY OF MOTION, COMMOTION, AND BIOPHYSICAL CONNECTION LEFT TO BE MEASURED, MODELED, AND UNDERSTOOD.

noes also have the potential to cause gravity-driven flows down seamount flanks (e.g., Walker et al., 2008). The associated biology (e.g., Metaxas, 2004) and microbiology (e.g., Huber and Holden, 2008) of active seamounts and the loss, retention, or capture of small particles (e.g., phytoplankton, larvae) in the face of local currents and turbulence; and (2) bio-communication, the one- or two-way transfer of larvae, for example, between neighboring seamounts or along seamount chains.

Expectations about seamount plankton distributions were initially based on observations of currents and patterns revealed by mathematical models of flow over seamounts. One of those expectations was that closed recirculation cells caused by incident steady flow or by incident long-period waves would, in effect, tether some particles to a seamount summit. That mechanism would create the conditions ultimately favorable to enhanced fish populations over seamounts, as is typically observed. That conceptual model of upwelling and particle trapping supporting increased concentrations of plankton has been examined in the field with mixed results (Dower and Mackas, 1996; Mullineaux and Mills, 1997; Wilson and Boehlert, 2004). Dower and Mackas (1996) found a plankton compositional, but not a biomass, effect at Cobb Seamount, where anticyclonic summit mean flows have been observed (Freeland, 1994; Codiga and Eriksen, 1997). Repeated observations at Cobb, a very shallow seamount, led to the view that enhanced phytoplankton populations are more event-like than typical (Comeau et al., 1995). At Fieberling Guyot, larval abundances were only slightly elevated over the summit when compared to far field samples (i.e., the flank and seamount base; Mullineaux and Mills, 1997). Repeated surveys over a period of seven years at Great Meteor Seamount covering different seasons (Mouriño et al., 2001) revealed an inconclusive picture of the possible existence of a persistent particle-trapping mechanism-phytoplankton enrichment was observed in some surveys as relative changes in species composition above 
the summit region, but not in others. Mouriño et al.s (2001) time-sequence results remind us that seasonal changes in mixed-layer depth and ambient stratification can have confounding effects that might otherwise be correlated with variations in impinging current features. More generally, all these observations give reason to challenge expectations of persistent enhanced phytoplankton populations above seamounts, whether caused by summit mean flow recirculation features or not. Mechanisms not involving primary production that would support increased aggregations of higher trophic levels above many (shallow and intermediate depth) seamounts are described by Genin (2004).

What happens to passive particles over a seamount? One approach to the question is to examine trajectories of particles (e.g., plankton/larvae) around seamounts using Lagrangian numerical models addressing loss, retention, and/or capture. Among the most detailed is the study by Goldner and Chapman (1997) who calculated trajectories of passive tracers released upstream of a seamount. They showed that both retention and loss depended upon the particle's initial placement over the topography. Subject to combined steady and weak tidal flow, those particles placed closer to the seamount summit were more likely to be retained. Tidal flow enhanced particle residence times in the nearsummit region. Chapman and Haidvogel (1992) estimated fluid particle residence times over idealized Gaussian-shaped seamounts of varying height subject to steady flow of varying strength and found enhanced particle trapping (up to 20 days) only for tall seamounts and rather weak inflows.
In a modeling study of Great Meteor Seamount, particles were retained in an undisturbed area above the summit for a period of 60 days (Beckmann and Mohn, 2002). Our own numerical experiments (Figure 6) using passive tracers in a model that does not account for summit boundary layer effects suggest that retention also depends on the spectral content of the impinging flows; if only steady or near-steady flow components are present in impinging flows, retention is poor. Retention is 10-20 times larger when near inertial motion is added to nearsteady flow or when all spectral components are used to force impinging flow. Restated, retention is reduced when too much of the incident currents' temporal variability is lost by approximating a complete (i.e., full) spectrum time series by a mean, or by a mean and a few tidal constituents (Figure 6D).

Also noteworthy in Figure 6A and B is the rapid (one-day) lateral displacement of the tracer in the few hundred meters above the seamount, which is caused by substantial vertical shear in the near-summit flow resulting from internal wave motion. In the last three of these four experiments, conditions once thought to be retention guarantors (i.e., a time-mean anticyclonic horizontal flow toroid at the summit, a cold dome, and a vertical circulation cell) all exist. Note, however, that these estimates of retention are based on calculations that assume particle passivity and particle sources at the seamount. Active behavioral strategies like swimming (Wilson and Boehlert, 1993, 2004), changing larval body density, or larvae finding safe harbor in small topographic features of a rough boundary layer (in the case of swimmers) should push these retention estimates upward. Retention fraction estimates will also vary with the specific topographic features of the seamount, ocean site conditions, and incident flow. Just as the population dynamics at a seamount as a whole does not occur in isolation of upstream populations (Morato et al., 2009), advection and capture of plankton/larvae from the far field into the seamount sphere of influence may also become important when local conditions at the seamount cannot sustain enhanced small particle populations over sufficiently long times (White et al., 2007).

Increased turbulence and current shears at the seamount surface should also increase sediment/detrital suspension, providing good conditions for suspension feeders like corals and sponges (e.g., Genin et al., 1986). Detritus settling from the overlying ocean may be selectively trapped around the seamount in boundary layers. Ocean eddies temporarily trapped by seamount topography may help retain detritus and perhaps dissolved nutrients as well. Any radial-vertical circulation cell above the seamount's summit (e.g., Mullineaux and Mills, 1997) and along its flanks might enhance the downflux of dissolved and particulate nutrients from surface layers and an upwelling flux from below summit depth.

An unsolved problem is to understand the time scales involved. Larvae of marine invertebrates may require 30 days to complete their planktonic stages, and persistent or recurrent biomass enrichment over several months may be needed for nektonic organisms to be attracted to and aggregated at seamounts. The issue is how to maintain supplies of nutrients, plankton, 

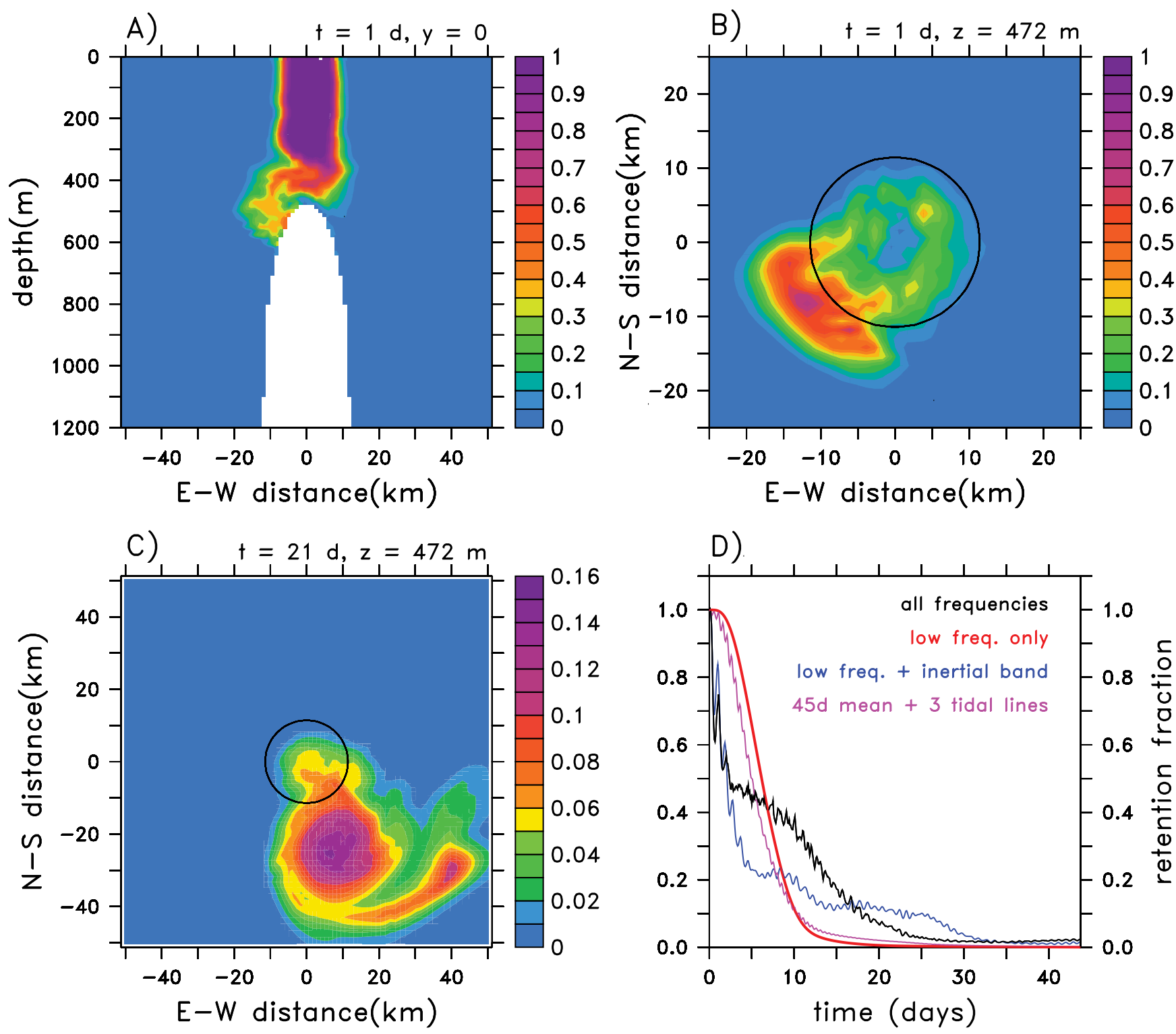

D)

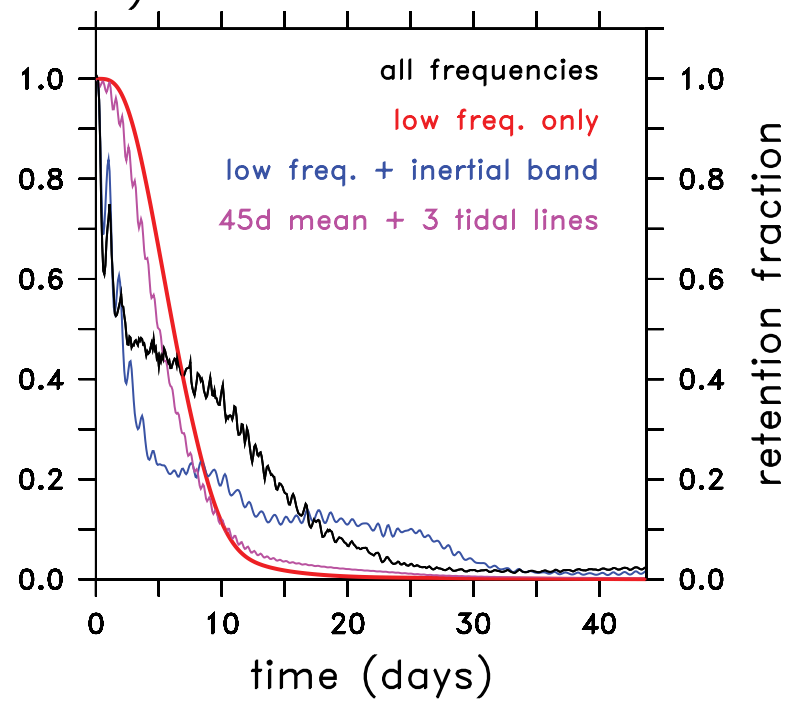

Figure 6. Particle dispersion over the top of a seamount for the case of a passive tracer initially filling a cylinder of 8-km radius from the seamount summit to the sea surface. The bathymetry and depth-varying stratification are hypothetical, while the multifrequency impinging currents were taken from a time series measured in deep water near Fieberling Guyot (Site B; Brink, 1995). Cross sections of concentration as a fraction of initial concentration (in color) after one day (A) on an east-west transect over the center of the seamount and (B) just $7 \mathrm{~m}$ above summit depth $(479 \mathrm{~m})$. The circle $(r=12 \mathrm{~km})$ in black represents the size of this seamount at a depth of $1145 \mathrm{~m}$. Results in A show how sheared velocities just over the summit quickly rearrange tracer distributions. (C) Tracer distribution at the same depth as (B) after 21 days showing longer time particle retention near the summit. Note the color scale change in panel C. (D) Retention fraction time series for four experiments, where the retention fraction is defined as the tracer mass at any time $t$ within a cylinder of radius $r<12 \mathrm{~km}$, and depth $z$ where $300<z<800 \mathrm{~m}$ compared to tracer mass within the same cylinder at the time of initial tracer placement. The four curves in this figure represent results for four different forcing time series: (1) when all available frequency constituents of the measured currents were employed (black), (2) when only the low-frequency ( $t>200 \mathrm{hr}$ ) constituents were used (red), (3) when only low plus inertial-band frequencies were used (blue), and (4) when the full time series is represented by a mean plus three tidal lines (purple). The retention fractions averaged over the interval day 40 to day 45 are $2.1 \%$, $0.04 \%, 1.2 \%$, and $0.1 \%$. In the case of full-spectrum forcing (black), $70 \%$ of the particles retained beyond 40 days are located in the 300-550-m depth interval. 
or detritus over the seamount long enough, or for that matter continually, in the presence of currents that may sometimes act to recirculate water at the summit but, at other times, could potentially strip the seamount of most of that population.

Our understanding of the effect on circulation and material transfer between neighboring seamounts (Roden, 1987; Zhang and Boyer, 1991) or along a seamount chain remains meager. Bio-communication between neighboring seamounts will be heavily indebted to regional circulation features. Consider neighboring seamounts, $A$ and $B$, of similar height. Unless particles can travel from $A$ to $B$ within a larval lifetime, no larval seeding of $B$ by A will occur. For sites where mean flows are large and unidirectional, B must lie within a relatively small solid angle downstream of A. Oscillatory flows can widen a larval plume from $A$ as it advects, increasing the probability of a plume encounter with B. A successful bio-communication between the two, however, will also depend on successful removal of particles from $A$ and successful capture of particles by B and/ or vice versa. Bio-communication will thus depend on all factors mentioned earlier as well as the distance and direction between the seamounts.

When the distance between the seamounts grows small, the circulation patterns, particularly those caused by oscillatory impinging flow, will be linked. The seeding of B by A and vice versa becomes more probable. The same may also happen with a chain of seamounts. A chain may present some aspects of an aggregated edifice to the larger ocean while maintaining some of the circulation and turbulence aspects of individual seamounts locally. Some anticyclonic flow near the composite summit under typical incident flow conditions can be expected. In the case of a seamount chain with appropriately small distances between member seamounts, the composite circulation is likely to cause the sharing of larval species between them. A complication to consider is seamounts in the chain having unequal heights. Then, vertical circulation to lift larvae from deeper levels to higher summits or settlement from higher levels to deeper summits may be required. Understanding biological connectivity along or between seamount chains may aid the debate about seamount endemism (i.e., whether some seamounts or seamount clusters are habitats for species found nowhere else). The prevalence of seamount endemism is still an open question (e.g., Stocks and Hart, 2007; Brewin et al., 2009; Shank, 2010).

\section{OUTLOOK}

Ocean physics and biophysical coupling at seamounts are topics poised for a new round of seamount exploration by virtue of recent and continuing advances in both field-based and modeling technologies. For example, use of autonomous underwater vehicles and tracers (e.g., $\mathrm{SF}_{6}$ ) should significantly improve the measurements of vertical circulation and the loss and retention of material in the presence of quasi-steady and oscillatory cross flows. Improvements in computing speed and memory, and advances in numerical modeling techniques, are opening the door for more finely resolved explorations of the motion and commotion at seamounts and the consequences they have for the transport and distribution of seamount biota and geochemicals.

Many interesting and challenging physical and biophysical problems remain to be studied. Much of the numerical modeling work on seamounts has been done on quite idealized configurations and with highly idealized impinging flows. How might results be changed if those aspects are revisited (i.e., if more realistic stratification, topography, and impinging flow time series were used)? How might swimming-capable biota affect their own retention at a seamount? To what extent do internal waves over a seamount contribute to plankton patchiness? How do neighboring seamounts bio-communicate and what are the physical oceanographic underpinnings of connectivity along a chain? How can heat and chemical fluxes from hydrothermally active seamounts with and without calderas be better estimated? As is true in other areas of ocean science, at seamounts there is plenty of motion, commotion, and biophysical connection left to be measured, modeled, and understood.

\section{ACKNOWLEDGMENTS}

We thank Susan Merle for creating the three-dimensional perspective view of Brothers Volcano (Figure 1), studies of which were funded in part by the National Oceanic and Atmospheric Administration's (NOAA) Office of Ocean Exploration and Research. We thank Lauren Mullineaux and an anonymous reviewer for detailed comments on the text. JWL is supported by NOAA’s Pacific Marine Environmental Laboratory and by NOAA's Vents Program. CM is jointly funded by 
the Griffith Geoscience Research

Awards Programme (Geological

Survey of Ireland) and the EU FP7

CoralFISH Programme (Grant agree-

ment no.: 213144). This is contribution

3298 from NOAA's Pacific Marine

Environmental Laboratory.

\section{REFERENCES}

Baines, P.G. 2007. Internal tide generation by seamounts. Deep-Sea Research Part I 54:1,486-1,508.

Baker, E.T., R.W. Embley, S.L. Walker, J.A. Resing, J.E. Lupton, K.-I. Nakamura, C.E.J. de Ronde, and G.J. Massoth. 2008. Hydrothermal activity and volcano distribution along the Mariana arc. Journal of Geophysical Research 113, B08S09, doi:10.1029/2007JB005423.

Baker, E.T., C.G. Fox, and J.P. Cowen. 1999. In situ observations of the onset of hydrothermal discharge during the 1998 submarine eruption of Axial Volcano, Juan de Fuca Ridge. Geophysical Research Letters 26(23):3,445-3,448.

Bashmachnikov, I., C. Mohn, J.L. Pelegri, A. Martins, F. Jose, F. Machín, and M. White. 2009. Interaction of Mediterranean water eddies with Sedlo and Seine Seamounts, Subtropical Northeast Atlantic. Deep-Sea Research Part II: Topical Studies in Oceanography 56(25):2,593-2,605.

Beckmann, A. 1995. Numerical modeling of timemean flow at isolated seamounts. Pp. 57-66 in Topographic Effects in the Ocean. P. Müller and D. Henderson, eds., Proceedings 'Aha Huliko'a Hawaiian Winter Workshop, January 17-20, 1995, Honolulu, HI.

Beckmann, A., and D.B. Haidvogel. 1997. A numerical simulation of flow at Fieberling Guyot. Journal of Geophysical Research 102:5,595-5,613.

Beckmann, A., and C. Mohn. 2002. The upper ocean circulation at Great Meteor seamount: Part II. Retention potential of the seamount-induced circulation. Ocean Dynamics 52:194-204.

Bograd, S.J., A.B. Rabinovich, P.H. LeBlond, and J. Shore. 1997. Observations of seamountattached eddies in the North Pacific. Journal of Geophysical Research 102:12,441-12,456.

Brewin, P.E., K.I. Stocks, D.B. Haidvogel, C. Condit, and A. Gupta. 2009. Effects of oceanographic retention of decapods and gastropod community diversity on seamounts. Marine Ecology Progress Series 383:225-237.

Brink, K.H. 1989. The effect of stratification on seamount-trapped waves. Deep-Sea Research 36:825-844.
Brink, K.H. 1990. On the generation of seamount-trapped waves. Deep-Sea Research 37:1,569-1,582.

Brink, K.H. 1995. Tidal and lower frequency currents above Fieberling Guyot. Journal of Geophysical Research 100:10,817-10,822.

Cenedese, C. 2002. Laboratory experiments on mesoscale vortices colliding with a seamount. Journal of Geophysical Research 107, C63053, doi:10.1029/2000JC000599.

Chapman, D.C. 1989. Enhanced subinertial diurnal tides over isolated topographic features. Deep-Sea Research 36:815-824.

Chapman, D.C., and D.B. Haidvogel. 1992. Formation of Taylor caps over a tall and isolated seamount in a stratified ocean. Geophysical and Astrophysical Fluid Dynamics 64:31-65.

Clark, M. 2001. Are deepwater fisheries sustainable? The example of orange roughy (Hoplostethus atlanticus) in New Zealand. Fisheries Research 51:123-135.

Codiga, D., and C.C. Eriksen. 1997. Observations of low-frequency circulation and amplified subinertial tidal currents at Cobb Seamount. Journal of Geophysical Research 102:22,993-23,007.

Comeau, L.A., A.F. Vezina, M. Bourgeois, and S.K. Juniper. 1995. Relationship between phytoplankton production and the physical structure of the water column near Cobb Seamount, Northeast Pacific. Deep-Sea Research Part I 42:993-1,005.

de Ronde, C.E.J., M.D. Hannington, P. Stoffers, I.C. Wright, R.G. Ditchburn, A.G. Reyes, E.T. Baker, G.J. Massoth, J.E. Lupton, S.L. Walker, and others. 2005. Evolution of a submarine magmatic-hydrothermal system: Brothers Volcano, southern Kermadec Arc, New Zealand. Economic Geology 100:1,097-1,133.

de Steur, L., D.M. Holland, R.D. Muench, and M.G. McPhee. 2007. The warm-water "Halo" around Maud Rise: Properties, dynamics and impact. Deep-Sea Research Part I 54:871-896.

Dower, J.F., and D.L. Mackas. 1996. Seamount effects in the zooplankton community near Cobb seamount. Deep-Sea Research Part I 43:837-858.

Embley, R.W., E.T. Baker, D.A. Butterfield, W.W. Chadwick Jr., J.E. Lupton, J.A. Resing, C.E.J. de Ronde, K.-I. Nakamura, V. Tunnicliffe, J.F. Dower, and S.G. Merle. 2007. Exploring the submarine ring of fire: Mariana Arc-Western Pacific. Oceanography 20(4):68-79.

Eriksen, C.C. 1991. Observations of amplified flows atop a large seamount. Journal of Geophysical Research 96:15,227-15,236.

Eriksen, C.C. 1998. Internal wave reflection and mixing at Fieberling Guyot. Journal of Geophysical Research 103(C2):2,977-2,994.
Ezer, T. 1994. On the interaction between the Gulf Stream and the New England seamount chain. Journal of Physical Oceanography 24(1):191-204.

Fernandez de la Mora, J. 2007. The fluid dynamics of Taylor cones. Annual Review of Fluid Mechanics 39:217-243.

Freeland, H. 1994. Ocean circulation at and near Cobb Seamount. Deep-Sea Research 41:1,715-1,732.

Garrett, C. 2003. Internal tides and ocean mixing. Science 301:1,858-1,859.

Garrett, C., and E. Kunze. 2007. Internal tide generation in the deep ocean. Annual Review of Fluid Mechanics 39:57-87.

Genin, A. 2004. Biophysical coupling in the formation of zooplankton and fish aggregation over abrupt topographies. Journal of Marine Systems 50:3-20.

Genin, A., and G.W. Boehlert. 1985. Dynamics of temperature and chlorophyll structures above a seamount: An oceanic experiment. Journal of Marine Research 43:907-924.

Genin, A., and J.F. Dower. 2007. Seamount plankton dynamics. Pp. 85-100 in Seamounts: Ecology, Fisheries, and Conservation. T.J. Pitcher, T. Morato, P.J.B. Hart, M.R. Clark, N. Haggan, and R.S. Santos, eds, Blackwell, Oxford, UK.

Genin, A., P.K. Dayton, P.F. Lonsdale, and F.N. Spiess. 1986. Corals on seamounts provide evidence of current acceleration over deep sea topography. Nature 322:59- 61.

Goldner, D.R., and D.C. Chapman. 1997. Flow and particle motion induced above a tall seamount by steady and tidal background currents. Deep-Sea Research Part I 44:719-744.

Herbette, S., Y. Morel, and M. Arhan. 2003. Erosion of a surface vortex by a seamount. Journal of Physical Oceanography 33:1,664-1,679.

Hogg, N.G. 1973. On the stratified Taylor column. Journal of Fluid Mechanics 58:515-537.

Holloway, P.E., and M.A. Merrifield. 1999. Internal tide generation by seamounts, ridges, and islands. Journal of Geophysical Research 104:25,937-25,951.

Huber, J.A., and J.F. Holden. 2008. Modeling the impact of diffuse vent microorganisms along mid-ocean ridges and flanks. Pp. 215-232 in Magma to Microbe, Modeling Hydrothermal Processes at Oceanic Spreading Centers. R.P. Lowell, J.S. Seewald, A. Metaxias, and M.R. Perfit, eds, Geophysical Monograph 178, American Geophysical Union, Washington, DC.

Huppert, H.E., and K. Bryan. 1976. Topographically generated eddies. Deep-Sea Research 23:655-679.

Koslow, J.A. 1997. Seamounts and the ecology of deep-sea fisheries. American Scientist 85:168-176. 
Kunze, E., and T.B. Sanford. 1996. Abyssal mixing: Where it is not. Journal of Physical Oceanography 26:2,286-2,296.

Kunze, E., and J.M. Toole. 1997. Tidally driven vorticity, diurnal shear, and turbulence atop Fieberling Seamount. Journal of Physical Oceanography 27:2,663-2,693.

Lavelle, J.W. 2006. Flow, hydrography, turbulent mixing, and dissipation at Fieberling Guyot examined with a primitive equation model. Journal of Geophysical Research 111, C07014, doi:10.1029/2005JC003224.

Lavelle, J.W., E.T. Baker, and G.A. Cannon. 2003. Ocean currents at Axial Volcano, a northeastern Pacific seamount. Journal Geophysical Research 108(C2), 3020, doi:10.1029/2002JC001305.

Lueck, R.G., and T.D. Mudge. 1997. Topographically induced mixing around a shallow seamount. Science 276:1,831-1,833.

Lupton, J., D. Butterfield, M. Lilley, L. Evans, K.-I. Nakamura, W. Chadwick Jr., J. Resing, R. Embley, E. Olson, G. Proskurowski, and others. 2006. Submarine venting of liquid carbon dioxide on a Mariana Arc Volcano. Geochemistry, Geophysics, Geosystems 7, Q08007, doi:10.1029/2005GC001152.

Metaxas, A. 2004. Spatial and temporal patterns in larval supply at hydrothermal vents in the northeast Pacific Ocean. Limnology and Oceanography 49:1,949-1,956.

Mohn, C., M. White, I. Bashmachnikov, F. Jose, and J.L. Pelegri. 2009. Dynamics at an elongated, intermediate depth seamount in the North Atlantic (Sedlo Seamount, $40^{\circ} 20^{\prime} \mathrm{N}$, $\left.26^{\circ} 40^{\prime} \mathrm{W}\right)$. Deep-Sea Research II Topical Studies in Oceanography 56(25):2,582-2,592.

Morato, T., C. Bulman, and T.J. Pitcher. 2009. Modelled effects of primary and secondary production enhancement by seamounts on local fish stocks. Deep-Sea Research II: Topical Studies in Oceanography 56(25)2,713-2,719.

Mouriño, B., E. Fernández, P. Serret, D. Harbour, B. Sinha, and R. Pingree. 2001. Variability and seasonality of physical and biological fields at the Great Meteor Tablemount (subtropical NE Atlantic). Oceanologica Acta 24:167-185.

Mullineaux, L.S., and S.W. Mills. 1997. A test of the larval retention hypothesis in seamount-generated flows. Deep-Sea Research Part I 44:745-770.

Noble, M., and L.S. Mullineaux. 1989. Internal tidal currents over the summit of Cross Seamount. Deep Sea Research 36:1,791-1,802.

Nycander, J., and J.H. Lacasce. 2004. Stable and unstable vortices attached to seamounts. Journal of Fluid Mechanics 507:71-94.

Owens, W.B., and N.G. Hogg. 1980. Oceanic observations of stratified Taylor columns near a bump. Deep-Sea Research 27:1,029-1,045.

Pitcher, T.J., and C. Bulman. 2007. Raiding the larder: A quantitative evaluation framework and strophic signature for seamount food webs.
Pp. 282-295 in Seamounts: Ecology, Fisheries, and Conservation. T.J. Pitcher, T. Morato, P.J.B. Hart, M.R. Clark, N. Haggan, and R.S. Santos, eds., Blackwell, Oxford, UK.

Pitcher, T.J., M.R. Clark, T. Morato, and R. Watson. 2010. Seamount fisheries: Do they have a future? Oceanography 23(1):134-144.

Proudman, J. 1916. On the motion of solids in a liquid possessing vorticity. Proceedings of the Royal Society of London A 92:408-424.

Resing, J.A., G. Lebon, E.T. Baker, J.E. Lupton, R.W. Embley, G.J. Massoth, W.W. Chadwick Jr., and C.E.J. de Ronde. 2007. Venting of acidsulfate fluids in a high-sulfidation setting at NW Rota-1 submarine volcano on the Mariana Arc. Economic Geology 102(6):1,047-1,061.

Richardson, P.L., A.S. Bower, and W. Zenk. 2000. A census of meddies tracked by floats. Progress in Oceanography 45(2):209-250.

Roden, G.I. 1987. Effects of seamounts and seamount chains on ocean circulation and thermohaline structure. Pp. 335-354 in Seamounts, Islands and Atolls. B. Keating, P. Fryer, R. Batiza, and G. Boehlert, eds, Geophysical Monograph 43, American Geophysical Union, Washington DC.

Rogers, A.D. 1994. The biology of seamounts. Advances in Marine Biology 30:305-350.

Royer, T.C. 1978. Ocean eddies generated by seamounts in the North Pacific. Science 199:1,063-1,064.

Schär, C., and H.C. Davies. 1988. Quasigeostrophic stratified flow over isolated finite amplitude topography. Dynamics of Atmosphere and Oceans 11:287-306.

Shank, T.M. 2010. Seamounts: Deep-ocean laboratories of faunal connectivity, evolution, and endemism. Oceanography 23(1):108-122.

Shapiro, G.I., S.L. Meschanov, and M.V. Emelianov. 1995. Mediterranean lens "Irving" after its collision with seamounts. Oceanologica Acta 18:309-318.

Staudigel, H., S.R. Hart, A. Pile, B.E. Bailey, E.T. Baker, S. Brooke, D.P. Connelly, L. Haucke, C.R. German, I. Hudson, and others. 2006. Vailulu'u seamount, Samoa: Life and death on an active submarine volcano. Proceedings of the National Academy of Sciences of the United States of America 103:6,448-6,453.

Stocks, K.I., and P.J.B. Hart. 2007. Biogeography and biodiversity of seamounts. Pp. 255-281 in Seamounts: Ecology, Fisheries, and Conservation. T.J. Pitcher, T. Morato, P.J.B. Hart, M.R. Clark, N. Haggan, and R.S. Santos, eds, Blackwell, Oxford, UK.

Sutyrin, G.G. 2006. Critical effects of a tall seamount on a drifting vortex. Journal of Marine Research 64(2):297-317.

Taylor, G.I. 1917. Motions of solids in fluids when the flow is not irrotational. Proceedings of the Royal Society of London A 93:99-113.
Taylor, G.I. 1923. Experiments on the motion of solid bodies in rotating fluids. Proceedings of the Royal Society of London A 104:213-218.

Toole, J.M., R.W. Schmitt, K.L. Polzin, and E. Kunze. 1997. Near-boundary mixing above the flanks of a mid-latitude seamount. Journal of Geophysical Research 102:947-959.

Verron, J., and C. Le Provost. 1985. A numerical study of quasi-geostrophic flow over isolated topography. Journal of Fluid Mechanics 154:231-252.

Walker, S.L., E.T. Baker, J.A. Resing, W.W. Chadwick Jr., G.T. Lebon, J.E. Lupton, and S.G. Merle. 2008. Eruption-fed particle plumes and volcaniclastic deposits at a submarine volcano: NW-Rota-1, Mariana Arc. Journal of Geophysical Research 113, B08S11, doi:10.1029/2007JB005441.

Wessel, P., D.T. Sandwell, and S.-S. Kim. 2010. The global seamount census. Oceanography 23(1):24-33.

White, M., I. Bashmachnikov, J. Aristegui, and A. Martins. 2007. Physical processes and seamount productivity. Pp. 65-84 in Seamounts: Ecology, Fisheries, and Conservation. T.J. Pitcher, T. Morato, P.J.B. Hart, M.R. Clark, N. Haggan, and R.S. Santos, eds., Blackwell, Oxford, UK.

Wilson, C.D., and G.W. Boehlert. 1993. Population biology of Gnathophausia longispina (Mysidacea, Lophogastrida) from a central North Pacific seamount. Marine Biology 115:537-543.

Wilson, C.D., and G.W. Boehlert. 2004. Interaction of ocean currents and resident micronekton at a seamount in the central North Pacific. Journal of Marine Systems 50:39-60.

Zhang, X.H., and D.L. Boyer. 1991. Current deflections in the vicinity of multiple seamounts. Journal of Physical Oceanography 21(8):1,122-1,138.

Zhang, X.Z., D.S. McGuinness, and D.L. Boyer. 1994. Narrow barotropic currents impinging on an isolated seamount. Journal of Geophysical Research 99:22,707-22,724. 